\title{
Fighting animal rights terrorism
}

\author{
A researcher recently announced his decision to stop working with primates after animal rights protesters targeted \\ his family. These events underscore the need for neuroscientists to support the Animal Enterprise Terrorism Act.
}

I n June, the Animal Liberation Front took responsibility for attempting to firebomb the home of Lynn Fairbanks, a primate researcher at the University of California, Los Angeles (UCLA). The Molotov cocktail was accidentally left at the wrong address, on the porch of her elderly neighbor, and did not explode because its timing device failed, but the terrorists' incompetence was apparently no consolation to her colleague Dario Ringach. The neuroscientist, who has young children, emailed animal rights groups in August to say that he had decided to stop doing research on monkeys, so "please don't bother my family anymore."

Like Fairbanks, Ringach had been targeted by the UCLA Primate Freedom Project, whose website still lists home addresses and phone numbers for several other colleagues, including neuroscientists Joaquin Fuster, John Schlag and Madeleine Schlag-Rey. Over several years, the researchers have been subjected to a campaign of harassment that included demonstrations at their homes and pamphlets distributed to their neighbors, as well as threatening phone calls and emails. Elsewhere, targets of similar protests have had abuse shouted through bullhorns or painted on their homes or cars, doorbells rung repeatedly, and windows smashed or doors broken down while family members were in the house. Animal-rights websites post the names of scientists' spouses and children, along with their ages and schools.

In the wake of these events, UCLA has announced that it is working to prepare a more effective response to future incidents, which might include lawsuits against activists. Unfortunately, this initiative comes too late for Ringach. The correct time for such reflection is before the problems become critical. Other universities would be well advised to give serious attention to the possibility that their researchers may be targeted and to develop a plan for dealing with such incidents before they occur.

Of course, activists are entitled to express their point of view vigorously through peaceful protests and to campaign for changes in the law and public opinion. However, such demonstrations against scientists at their homes are clearly aimed at intimidating individual researchers and their families, not at persuading the public. Unfortunately, some extremists within the animal-rights movement are attempting to impose their views on others through violence and threats, rather than pursuing change through the political system. "I think Dario Ringach is a poster boy for the concept that the use of force or the threat of force is an effective means to stop people who abuse animals," Animal Liberation Front spokesman Jerry Vlasak told the Los Angeles Times. People who act on this philosophy deserve to be treated as criminals, not as debating partners.

In recent years, animal-rights groups have developed sophisticated tactics to exploit loopholes in the law by harassing employees of animal research organizations and the companies with which they do business.
Law enforcement agencies and universities have had difficulty protecting researchers from these attacks because even if the perpetrators are identified and convicted, offenses like trespassing and disturbing the peace are misdemeanors that carry minor penalties. These tactics, which originated in the United Kingdom (UK), have proven successful in other countries, as we have discussed previously ${ }^{1}$. The UK has also led the way in responding to such attacks by amending the Serious Organized Crime Act to define animal extremism as terrorism.

Senator James Inhofe of Oklahoma and Congressman Thomas Petri of Wisconsin recently introduced a bill to close loopholes in United States (US) law. The Animal Enterprise Terrorism Act would extend previous legislation to cover attacks on individual employees or on companies that do business with animal research organizations. Had it been passed in time, this law would have allowed federal officers to respond effectively to the protests at UCLA, by criminalizing any pattern of conduct (two or more incidents) that intentionally place a person or that person's family in reasonable fear of death or serious injury by threats, vandalism, property damage, trespass, harassment or intimidation. The act also spells out increased penalties for violations, which range from 6 months in jail for nonviolent obstruction of a business that causes no injury up to life imprisonment for the death of a person.

Civil rights groups initially raised concerns about the bill's potential to restrict constitutionally protected speech, including legitimate consumer boycotts. To address these concerns, the House Judiciary Committee, in cooperation with the American Civil Liberties Union, has modified the bill's language to make it explicit that the law would not prohibit "any expressive conduct (including peaceful picketing or other peaceful demonstration)". There is precedent for legislation that balances the need to prevent harassment of individuals against respect for civil liberties, in anti-stalking laws that aim to protect women from domestic violence.

The recent events in Los Angeles have had unintended consequences for the animal-rights movement. Although the majority of activists hope to sway public opinion away from supporting animal research, the acts of extremists have drawn media attention instead to their tactics of harassment and intimidation of individuals, which do not enjoy public support. In particular, the bomb attempt and Ringach's announcement caught the attention of Senator Dianne Feinstein of California, who in September signed on as a cosponsor of the Animal Enterprise Terrorism Act, making it a bipartisan initiative and increasing its odds of passing in the legislature. We urge all US neuroscientists to contact their senators and representatives to demand that this bill be brought to a vote before Congress adjourns for the year.

1. Nat. Neurosci. 7, 413 (2004). 